Original Research Article

\title{
Comparative study of once and twice application of topical 5\% permethrin in patients of scabies
}

\author{
Rashmi Singh $^{1 *}$, Sujata Singh ${ }^{2}$, Jitendra Pal Singh ${ }^{3}$
}

\begin{abstract}
${ }^{1}$ Department of Pharmacology, Rajshree Medical Research Institute (RMRI), Bareilly, Uttar Pradesh, India

${ }^{2}$ Department of Pharmacology, Shri Ram Murti Smarak Institute of Medical Sciences (SRMS IMS), Bareilly, Uttar Pradesh, India

${ }^{3}$ Shyam Kamal Skin Clinic, Bareilly, Uttar Pradesh, India
\end{abstract}

Received: 02 June 2017

Accepted: 09 June 2017

*Correspondence to:

Dr. Rashmi Singh,

Email: rashmidrlko@ yahoo.co.in

Copyright: (C) the author(s), publisher and licensee Medip Academy. This is an openaccess article distributed under the terms of the Creative Commons Attribution NonCommercial License, which permits unrestricted noncommercial use, distribution, and reproduction in any medium, provided the original work is properly cited.

\begin{abstract}
Background: Scabies is an itchy skin condition caused by the Sarcoptes scabiei which is treated by various topical and oral drugs. Among the all topical drugs, permethrin has been the drug of choice for the treatment of scabies. Therefore the aim of this study was to compare the efficacy of once and twice (repeat after one week) application of topical 5\% permethrin in patients of scabies.

Methods: This was an observational study in which a total number of 52, clinically diagnosed patients of scabies, receiving the topical $5 \%$ permethrin once (group A) and twice (repeat after one week-group B), were observed for treatment outcome. Treatment was evaluated at intervals of 1, 2, 3 and 4 weeks by improvement or decrease in number of lesions and severity of pruritus. The efficacy of both the methods was compared statistically within and between the two groups.

Results: A significant $(\mathrm{p}=<0.05)$ decrease in number of lesions as well as pruritus was observed at each follow up visit separately in both the groups. Between the groups comparison demonstrated a significant $(p=<0.05)$ decrease in number of lesions as well as pruritus in group B, at follow up visit of 2 weeks while at the end of 4 weeks there was no difference in cure rate of both groups. Conclusions: Both the treatment modalities revealed equal efficacy at the end of 4 weeks. However, twice application of topical 5\% permethrin showed faster and significant improvement at 2 week follow up in reference to both the number of lesions and severity of pruritus.
\end{abstract}

Keywords: Permethrin, Scabies, Topical

\section{INTRODUCTION}

Scabies is a highly contagious skin infestation caused by a mite known as the Sarcoptes scabiei. It is an ectoparasitic infection caused in humans as a result of direct skin-to-skin contact; fomite transmission from mites attached to clothing, bedding, and towels is uncommon. ${ }^{1}$ In developing countries, it is still a major public health problem because it is highly prevalent and complications are frequent. It is one of the main reasons for consultations in non-specialized primary health-care centres. $^{2}$

Infestation occurs when the pregnant female mite burrows through the epidermis, laying eggs from which the larvae emerge after two to three days and again these larvae dig new burrows and form the various skin lesions. The finger webs are the preferred sites of entry, but may soon spread to forearms, trunk, genitals and lower legs. ${ }^{3}$ The skin lesions of scabies are due to both, the burrows of the mites and to more widespread inflammatory 
response of the skin, caused by hypersensitivity reaction to the mites and their saliva or excreta. ${ }^{4-6}$ The classical features include generalized itching that is more intense at night, causing discomfort to the patient; however, complications can occur as a result of secondary bacterial infection which requires systemic antimicrobial therapy. ${ }^{7-10}$

Numerous modalities of treatment have been used for the treatment and prevention of scabies and the mainstay of therapy in the present era is usually topical which includes application of sulfur, lindane, benzyl benzoate, malathion, crotamiton monosulfiram, and permethrin etc. $^{11}$ But this requires prolonged and repeated application. Resistance to some of these drugs has also been reported.

Therefore, the search for an ideal scabicide is going on, which should be effective against adult mite and eggs, easily applicable or orally administered, non-sensitizing, non-irritating, non-toxic, economical, early and high cure rate and safe in all age groups. ${ }^{12}$

Currently, topical $5 \%$ permethrin cream is considered as the drug of choice in the management of scabies which is a synthetic pyrethroid agent and was approved by the Food and Drug Administration (FDA) in $1989 .{ }^{13}$ It is costly and because of long duration application, it leads to poor compliance in patients and family contacts, making community control of scabies difficult. ${ }^{14}$ But despite of its high cost it is commonly used as an effective treatment for scabies. Therefore the present study has been undertaken with the aim of comparing the effect of once and twice application of $5 \%$ permethrin in a week in patients of scabies.

\section{METHODS}

The study was conducted in an Outpatient Department of Private Skin Clinic of Bareilly from March 2015 to October 2015.

This was an observational study in which all the consecutive patients, attending the outdoor patient department, diagnosed as scabies; who were prescribed topical 5\% permethrin once application (Group A) or twice application (repeat after one week) (Group B), were considered. After complete history and examination, the patients who were $<5$ years, $>65$ years, pregnant women, lactating women, patient who received any antiscabicidal therapy in last one month, patients with any systemic disease or any seizure disorders were excluded from the study. Informed consent was obtained only from those 52 patients who participated in the study.

The treatment consists of application of 5\% permethrin cream on the body, which was very well explained to the patients by the clinician. They were advised to apply the cream below jaw up to toe and take a scrubbed bath, 12 hours later. They were also advised to wash their clothes and bedding in boiling water and not to take any antipruritic drug or any other topical medication during the treatment. Standard instructions about the nature of disease and importance of treating all family members and close contacts were also given to the patients. Those who were prescribed twice application were advised to repeat application after 1 week and follow the same instructions as before.

The demographic data and observations regarding the signs, symptoms and number of lesions were noted in predesigned tables and body diagram sheets (not shown) separately for both the groups before and after treatment at 1 week; 2 weeks, 3 weeks and 4 weeks follow up visits. Treatment was considered to be effective if there was no emergence of new lesion or decrease in number of lesions on the basis of their grading and signs of improvement of itching on the basis of VAS score. It was considered as failure if there was still marked itching and appearance of new lesion at the end of 2 weeks. The results of the study were analyzed statistically using the Microsoft excel software version 2007 in two groups using the $\mathrm{t}$ test, chi square test and fisher exact test and $\mathrm{p}$ value $<0.05$ was considered significant.

\section{RESULTS}

Table 1: Demographic characteristics of the study population.

\begin{tabular}{|c|c|c|c|}
\hline $\begin{array}{l}\text { Demographic } \\
\text { data }\end{array}$ & $\begin{array}{l}\text { Group A } \\
\text { (Once } \\
\text { application } \\
\text { of } 5 \% \\
\text { permethrin) }\end{array}$ & $\begin{array}{l}\text { Group B } \\
\text { (Twice } \\
\text { application of } \\
\mathbf{5 \%} \\
\text { permethrin) }\end{array}$ & $\begin{array}{l}\text { p } \\
\text { Value }\end{array}$ \\
\hline \multicolumn{4}{|c|}{ Age (years) of the patients (Mean \pm SD) } \\
\hline & $25.05 \pm 15.314$ & $23.5 \pm 16.001$ & 0.7607 \\
\hline Sex ratio (M:F) & $13: 7$ & $14: 6$ & 0.2497 \\
\hline \multicolumn{4}{|l|}{ Education } \\
\hline Literate & $12(60 \%)$ & $13(65 \%)$ & \multirow{2}{*}{0.2428} \\
\hline Illiterate & $8(40 \%)$ & $7(35 \%)$ & \\
\hline \multicolumn{4}{|c|}{ Socio economic status } \\
\hline Low & $14(70 \%)$ & $13(65 \%)$ & \multirow{3}{*}{0.9140} \\
\hline Middle & $3(15 \%)$ & $4(20 \%)$ & \\
\hline High & $3(15 \%)$ & $3(15 \%)$ & \\
\hline \multicolumn{4}{|c|}{ Family history present } \\
\hline & $15(75 \%)$ & $15(75 \%)$ & 0.2836 \\
\hline \multicolumn{4}{|l|}{ Diet } \\
\hline Vegetarian & $8(40 \%)$ & $4(20 \%)$ & \multirow{2}{*}{0.1092} \\
\hline Non-vegetarian & $12(60 \%)$ & $16(80 \%)$ & \\
\hline \multicolumn{4}{|l|}{ Locality } \\
\hline Local & $19(95 \%)$ & $17(85 \%)$ & \multirow{2}{*}{0.2495} \\
\hline Outsiders & $1(5 \%)$ & $3(15 \%)$ & \\
\hline
\end{tabular}

A total number of 108 patients were diagnosed as scabies, among which 52 patients were included for observation on the basis of prescription, inclusion and exclusion criterion. Out of these 52 patients, 12 patients did not complete the 4weeks of follow up visits. Overall only 20 patients in Group A (once application) and 20 patients in 
Group B (twice application) were observed for treatment outcome. There were no significant differences $(p>0.05)$ in age, gender, socioeconomic status, education, family history and diet between the two groups. Both the groups were comparable. The mean age of the patients in group A and group B was 25.05 \pm 15.314 years and 23.5 \pm 16.001 years respectively and ratio of males was more in both the groups. Most of the patients in both the groups were literate, nonvegetarian, belong to local Bareilly and of low socioeconomic class (Table 1).

On analyzing the data of number of lesions, a significant reduction $(\mathrm{p}=<0.05)$ was observed at each follow up visit separately in both the groups and when comparison was done between the groups, a significant difference in improvement $(\mathrm{P}=0.0236)$ (Figure 1$)$ was found only at $2^{\text {nd }}$ week follow up visit that was more in patients of group $\mathrm{B}$, though all the patients were cured at $4^{\text {th }}$ week of follow up.

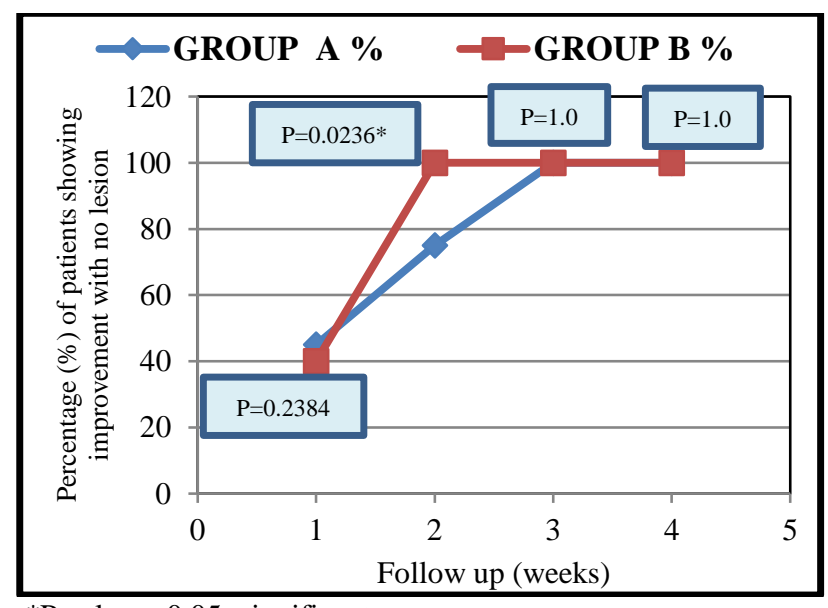

$* \mathrm{P}$ value $<0.05=$ significant

Figure 1: Percentage of patients showing improvement with no lesions.

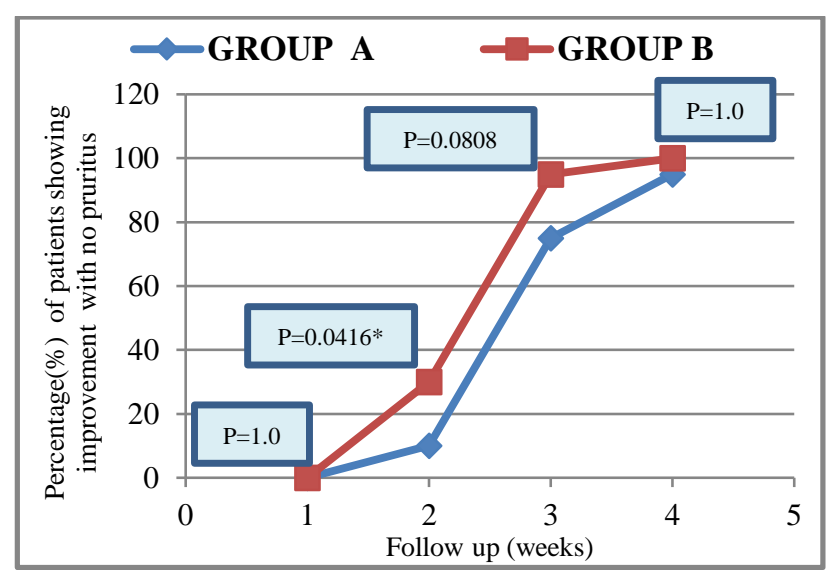

$* \mathrm{P}$ value $<0.05=$ significant

Figure 2: Percentage of patients showing improvement with no pruritus.

Similar to the improvement in number of lesions, severity of pruritus (on the basis of VAS score) was significantly decreased $(\mathrm{p}=<0.05)$ in both the groups separately at each follow up visit and between the group comparison demonstrated a significant $(\mathrm{P}=0.0416)$ (Figure 2) improvement in pruritus $(\mathrm{VAS}=0)$ only at $2^{\text {nd }}$ week follow up visit. Improvement in the pruritus at other follow ups was not significantly different. None of the patients complained of pruritus after 4 weeks.

Regarding the adverse drug reactions, in our study 3 patients in group A and 4 patients in group B presented with severe burning sensation. None of patients presented with treatment failure.

\section{DISCUSSION}

Scabies occurs worldwide and estimated to infect over 300 million cases each year. ${ }^{4}$ The infection is endemic in many impoverished communities, but prevalence rates vary widely and the seasonal outbreaks are probably related to crowding and population movements. ${ }^{5,8,15}$ It is common all over the world and it affects people of all races and social classes. ${ }^{16}$ Scabies spreads quickly in crowded conditions where there is frequent skin-to skin contact, sharing of clothes, towels and bedding between people. In our study, most of the patients in both the groups were young (below 30 years) literate, nonvegetarian and of low socioeconomic class. There were more number of males than females and the family history of contacts was present in maximum number of patients but there were no significant differences in all the demographic data between the two groups which were in accordance with previous studies. ${ }^{17}$

Permethrin 5\% dermal cream, the most effective topical agent, is the treatment of choice for scabies in many countries. ${ }^{9}$ It is well tolerated and has low toxicity. ${ }^{18}$ It acts by disrupting the sodium channel current, resulting in delayed repolarization, paralysis, and death of the parasite by acting at all the stages of the life cycle. ${ }^{19}$

In this study, both the treatment modalities (once and twice application of cream) revealed equal efficacy at the end of 4 weeks. However, twice application of topical 5\% permethrin had shown faster and significant improvement at 2 week follow up in reference to both the number of lesions and severity of pruritus. As we know that, the topical application ensures the maximum concentration of the drug in the skin accounting for the superior efficacy, therefore twice application of the drug by repeating it after one week showed early and excellent cure rates that may be because of complete disruption of residual remnants of parasite. ${ }^{17,20}$

None of the patients experienced worsening of the infestation or treatment failure during the study; but 3 patients in group A and 4 patients in group B reported the severe burning sensations that may due to absorption of dead parasite proteins. ${ }^{19}$ 
Since the difference in effectiveness obtained by applying permethrin once or twice a week was equal at last follow up, but there was early and fast relief by twice application of the same drug. Therefore, we can recommend twice application of permethrin for common scabies but there is need to carry out more studies to further validate the results.

\section{ACKNOWLEDGEMENTS}

The authors are thankful to all the patients who gave their full support to carry out this research work easily.

\section{Funding: No funding sources}

Conflict of interest: None declared

Ethical approval: The study was approved by the Institutional Ethics Committee

\section{REFERENCES}

1. Mellanby K. The development of symptoms, parasitic infection and immunity in human scabies. Parasitol. 1944;35:197-206.

2. Fatimata Ly, Caumes E, Ndaw CAT, Ndiaye B, Mahé A. Ivermectin versus benzyl benzoate applied once or twice to treat human scabies in Dakar, Senegal: a randomized controlled trial. Bulletin of the World Health Organization. 2009;87:424-30.

3. Tripathi KD. Antiseptics, Disinfectants and Ectoparasiticides. In: Essential of medical pharmacology. $7^{\text {th }}$ Ed. India, Jaypee Publisher; 2013;902-903.

4. Chosidow O. Scabies. New England Journal of Medicine. 2006 Apr 20;354(16):1718-27.

5. Hengge UR, Currie BJ, Jager G, Lupi O, Schwartz RA. Scabies: a ubiquitous neglected skin disease. Lancet Infect Dis. 2006;6:769-79.

6. Johnston G, Scabies SM. diagnosis and treatment. $\mathrm{Br}$ Med J. 2005;331:619-22.

7. Johnstone P, Scabies SM. Clin Evid. 2006;15:228490.

8. Heukelbach J, Feldmeier H. Scabies. Lancet 2006;367:1767-74.
9. McCarthy JS, Kemp DJ, Walton SF, Currie BJ. Scabies. More than just an irritation. Postgrad Med J. 2004;80:382-7.

10. Roberts LJ, Huffam SE, Walton SF, Currie BJ. Crusted scabies: clinical and immunological findings in seventy-eight patients and a review of the literature. J Infect. 2005;50:375-81.

11. Mumcuoglu KY, Gilead L. Treatment of scabies infestations. Parasite. 2008;15:248-51.

12. Karthikeyan K. Treatment of scabies: Newer perspectives. Postgrad Med J. 2005 Jan 1;81(951):711.

13. Orkin M, Maibach HI. Scabies therapy. In Seminars in dermatology. 1993 Mar;12(1):22-5.

14. Buffet M, Dupin N. Current treatments for scabies. Fundam Clin Pharmacol. 2003;17:217-25.

15. Green MS. Epidemiology of scabies. Epidemiol Rev. 1989;11:126-50.

16. Goldust M, Rezaee E, Raghifar R, Hemayat S. Treatment of scabies: topical ivermectin vs. permethrin $2.5 \%$ cream. Annals of Parasitology 2013;59(2):79-84.

17. Sharma R, Singal A. Topical permethrin and oral ivermectin in the management of scabies: a prospective, randomized, double blind, controlled study. Ind J of Der, Vener and Lepr. 2011;77:581-6.

18. Johnston G, Sladden M. Scabies: diagnosis and treatment. Br Med J. 2005;331:619-22.

19. Currie BJ, McCarthy JS. Permethrin and ivermectin for scabies. N Engl J Med. 2010;362:717-25.

20. Chhaiya SB, Patel VJ, Dave JN, Mehta DS, Shah HA. Comparative efficacy and safety of topical permethrin, topical ivermectin, and oral ivermectin in patients of uncomplicated scabies. Ind $\mathrm{J}$ of Der, Vener and Lepr. 2012;78:605-10.

Cite this article as: Singh R, Singh S, Singh JP. Comparative study of once and twice application of topical $5 \%$ permethrin in patients of scabies. Int $\mathbf{J}$ Basic Clin Pharmacol 2017;6:1608-11. 